\title{
ANALISIS DESAIN KETINGGIAN TANGGUL LAUT UNTUK MEMINIMALISIR HILANGNYA GARIS PANTAI PASCA TSUNAMI TAHUN 2018 DI TELUK PALU
}

\section{THE ANALYSIS ON SEA WALL HEIGHT DESIGN TO MINIMALIZED THE LOST OF COASTLINE AFTER TSUNAMI ON PALU COAST IN 2018}

\author{
Bondan Fiqi Riyalda ${ }^{1}$ \\ ${ }^{1}$ Pusat Teknologi Reduksi Risiko Bencana (PTRRB) - BPPT \\ Gedung 820, GEOSTECH, PUSPIPTEK, Kota Tangerang Selatan, telepon: (021) 75791378 \\ e-mail: bondan.fiqi@bppt.go.id
}

\begin{abstract}
In 2018, Palu coast area residents had to experience the hardest time in their life. It was when the earthquake, liquefaction and tsunami happened at the same time at dusk. It happened when people were coming back home from their activities. The catastrophe caused the loss of many lives and noticeable amount of infrastructure damage. Including the new massive continuing problem, which is erosion of the coastline of Palu Bay that significantly happened after the catastrophe. In this context, the government and the people need to rise up to rebuild the infrastructure as healing stage, in order to do so, sea wall needed to be rebuilt to minimalize the eradication. The sea wall must meet the scientific requirements, in order to prevent technological failures that causes nation to loss. After several analysis has been made towards related references and simulation using Delft $3 D$ application, that in last 100 years, the predictions of wind speed is $10.35 \mathrm{~m} / \mathrm{s}$ on Palu Coast area, tide height reached $1.45 \mathrm{~m}$; storm surge maximum value around $0.086 \mathrm{~m}$; wave condition between 0.90 to $1.25 \mathrm{~m}$; average of annual sea level rise is $0.75 \mathrm{~cm}$. If calculated correctly, the height of the sea wall construction design can be recommended at $3.186-3.536 \mathrm{~m}$.
\end{abstract}

Keywords: Sea wall, simulation, tide, wave, sea level rise

\begin{abstract}
ABSTRAK
Tahun 2018 cukup berat dirasakan oleh warga pesisir Teluk Palu, dimana bencana alam seperti gempabumi, likuefaksi, dan tsunami harus terjadi di saat bersamaan dan pada waktu senja hari. Ketika hampir semua masyarakat berada di rumah setelah seharian beraktivitas. Peristiwa tersebut menyebabkan korban jiwa yang sangat banyak, dan begitu juga kerusakan infrastruktur yang tidak sedikit. Termasuk munculnya problem baru yang masiv dan akan terus berjalan, berupa terkikisnya garis pantai pada wilayah Teluk Palu yang meningkat signifikan pasca kejadian tersebut. Oleh sebab itu, pemerintah dan masyarakat harus bangkit untuk membangun kembali infrastruktur sebagai langkah pemulihan, termasuk perlu dibuat sebuah tanggul laut untuk meminimalisir terkikisnya garis pantai pada wilayah Teluk Palu. Tanggul laut yang dibangun harus memenuhi kriteria sains, supaya tidak terjadi gagal teknologi yang menyebabkan kerugian negara. Setelah dilakukan pengkajian terhadap beberapa referensi terkait dan simulasi menggunakan aplikasi Delft 3D, maka direkomendasikan bahwa pada kurun waktu 100 tahun terakhir prediksi kecepatan angin adalah 10,35 m/s di area Teluk Palu, maka tinggi pasang surut air laut mencapai $1,45 \mathrm{~m}$; nilai maksimum storm surge sekitar $0,086 \mathrm{~m}$; kondisi wave antara 0,90 hingga $1,25 \mathrm{~m}$; dan sea level rise rata-rata per tahun adalah $0,75 \mathrm{~cm}$. Apabila dikalkulasi akan mendapat rekomendasi ketinggian desain konstruksi tanggul laut mencapai 3,186-3,536 m.
\end{abstract}

Kata kunci: Tembok laut, simulasi, pasang surut, gelombang, kenaikan permukaan laut 


\section{PENDAHULUAN}

\subsection{Latar Belakang}

Hari Jumat, 28 September 2018 jam 17.02 WITA masyarakat dikejutkan dengan guncangan gempabumi dengan magnitudo 7,4 mengguncang separuh Pulau Sulawesi yang menyebabkan tsunami. Episentrum berada pada koordinat 0,18 Lintang Selatan, 119,85 Bujur Timur dengan jarak $26 \mathrm{~km}$ utara Donggala pada kedalaman $10 \mathrm{~km}$ (Pribadi et al., 2019). Kejadian bencana gempabumi, likuefaksi, dan tsunami terjadi di saat bersamaan dan pada waktu senja hari, ketika hampir semua masyarakat berada di rumah setelah seharian beraktivitas. Peristiwa tersebut menyebabkan korban jiwa yang sangat banyak, dan begitu juga kerusakan infrastruktur yang tidak sedikit. Lokasi yang terdampak adalah Kota Palu, Kabupaten Donggala, Kabupaten Sigi, dan Kabupaten Parigi Moutong. Data korban 2.101 orang meninggal, 4.438 luka berat/rawat inap, 83.122 luka ringan/rawat jalan, 1.373 hilang, 173.552 bangunan rusak (http://pusatkrisis.kemkes.go.id).

Tahapan menghadapi bencana terdapat tiga fase, yaitu evakuasi, normalisasi, dan rekonstruksi (Fedryansyah et al., 2016). Tahapan evakuasi sudah diawali dengan penerjunan puluhan orang TNI AL menggunakan helikopter Hercules langsung ke wilayah Teluk Palu. Selanjutnya BPBD, Pemerintah Daerah, PMI, BNPB, Tim SAR, Polisi, TNI AD, dan masyarakat saling bahu-membahu untuk melakukan evakuasi korban jiwa.

Selanjutnya, terdapat tahap normalisasi di lakukan oleh banyak kalangan, dari mulai instansi pemerintah, swasta, badan usaha, dan bahkan masyarakat luas yang menaruh simpatinya terhadap korban gempa dan tsunami di Teluk Palu. Salah satunya adalah program operasi bakti teknologi untuk Palu menggunakan Kapal Riset Baruna Jaya I, yang mengangkut 200 ton sumbangan dari berbagai Kementerian dan Lembaga seperti Ristekdikti, BUMN, dan bantuan organisasi masyarakat. Selain itu juga ekspedisi tersebut melakukan pemetaan bathymetry laut dalam, di perairan Teluk Palu-Donggala dan di sebelah utara Teluk Palu. Survei ini untuk mengetahui topografi dasar laut pasca gempa dan tsunami di Donggala-Palu (http://rri.co.id).

Selanjutnya adalah tahap rekonstruksi, dimana pembangunan kembali infrastruktur pasca bencana. Rekonstruksi pemulihan telah dilakukan oleh banyak kalangan, dari mulai instansi kementerian, badan usaha, swasta, dan bahkan masyarakat umum. Di sisi lain, muncul masalah baru yang masiv dan akan terus berjalan, berupa terkikisnya garis pantai pada wilayah Teluk Palu yang meningkat signifikan pasca kejadian tersebut.

Terkikisnya garis pantai pada wilayah Teluk Palu, menyebabkan kerugian yang cukup besar. Sektor pariwisata wilayah pantai akan tereduksi, pengusaha tambak akan merugi karena lahan tambaknya hilang, tidak optimalnya fungsionalitas dermaga karena jarak antara daratan dan perairan laut makin menjauh, serta masih banyak lagi efek buruk dari terkikisnya garis pantai. Oleh sebab itu, pemerintah mengupayakan untuk membangun kembali infrastruktur sebagai langkah pemulihan, termasuk perlu dibuatnya sebuah tanggul laut untuk meminimalisir terkikisnya garis pantai pada wilayah Teluk Palu. Investasi pada pembangunan tanggul laut dapat meningkatkan prospek ekonomi pada masyarakat di kawasan itu (Zulham, 2014).

Pembangunan tanggul laut diperkirakan akan mendorong terjadinya trade off pada lapangan usaha perikanan, namun akan memberi peluang besar bagi masyarakat perikanan karena munculnya berbagai lapangan usaha baru (Suharto, 2008).

\subsection{Tujuan}

Tujuan dari kajian ini adalah membuat analisis desain ketinggian tanggul laut yang cocok untuk meminimalisir hilangnya garis pantai pasca tsunami tahun 2018 di Teluk Palu berdasarkan parameter tide, storm surge, dan wave yang disimulasikan menggunakan aplikasi Delft 3D, serta rata-rata sea level rise yang diambil dari beberapa sumber.

\section{METODE PENELITIAN}

Metode penelitian yang digunakan adalah metode studi kasus, dimana lokasi yang dijadikan fokus dari studi kasusnya adalah wilayah Teluk Palu, sehingga dilakukan eksplorasi, kolaborasi, implementasi/simulasi, dan evaluasi untuk mendapatkan hasil analisis desain ketinggian tanggul yang sesuai pada daerah tersebut. Datadata dasar (bathymetry, kecepatan angin, dan lain-lain) yang berhubungan dengan rekomendasi ketinggian desain konstruksi tanggul laut pada daerah tersebut dilakukan simulasi/diimplementasikan dengan software simulasi, supaya mendapatkan data tide, storm surge, dan wave/gelombang laut yang menunjang proses pembahasan/analisis lanjutan mengenai rekomendasi ketinggian desain konstruksi tanggul laut yang dikaji pada penelitian ini.

Adapun langkah-langkah simulasi tersebut menggunakan aplikasi Delft 3D dengan melakukan pemodelan tide, storm surge, dan pemodelan wave. Selain itu, data sea level rise 
dinilai perlu ditambahkan untuk menambah parameter referensi ketinggian desain konstruksi tanggul laut. Pada penelitian dan pengkajian ini, penentuan sea level rise didapat dari beberapa sumber yang relevan.

\section{IMPLEMENTASI DAN PEMBAHASAN}

Implementasi/simulasi

menggunakan software perlu dilakukan untuk mendapatkan sebuah data tide, storm surge, dan wave/gelombang laut. Selanjutnya data-data tersebut dibahas/dianalisis untuk menentukan suatu parameter yang pada bagian kesimpulan akan dikalkulasikan beserta hasil pembahasan/analisis eksplorasi referensireferensi yang berhubungan dengan sea level rise.

\subsection{Tide dan Storm Surge}

Pada kenaikan muka air laut dan gelombang pada pemodelan ini menggunakan open boundaries pada deep sea. Pada bab ini akan dilakukan pemodelan dengan referensi kedalaman laut terdalam bernilai $800 \mathrm{~m}$ pada wilayah Teluk Palu. Tide dan storm surge sangat berpengaruh dalam pembuatan tanggul laut. Pada analisis pemodelan ini menggunakan aplikasi Delft 3D, dimana terdapat Delft dashboard yang perlu diinstall terlebih dahulu.

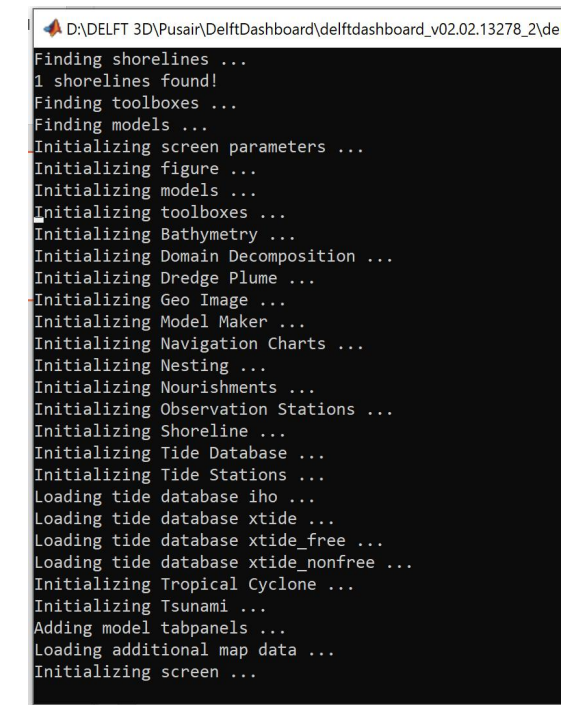

Gambar 1. Instalasi Delft Dashboard

Delft dashboard digunakan untuk mempermudah pengguna aplikasi delft dalam membuat grid. Jadi, wilayah yang akan dimodelkan diisi dengan menggunakan grid. Semakin presisi wilayah grid yang digunakan, maka semakin mendekati pemodelan yang seharusnya. Teknik, akurasi, dan ketelitian merupakan kunci menghasilkan grid yang baik. Wilayah yang dimasukkan ke dalam grid hanya area air pada teluk, tidak sampai sungai, karena fokus pada tanggul laut (Delft, 2019a).

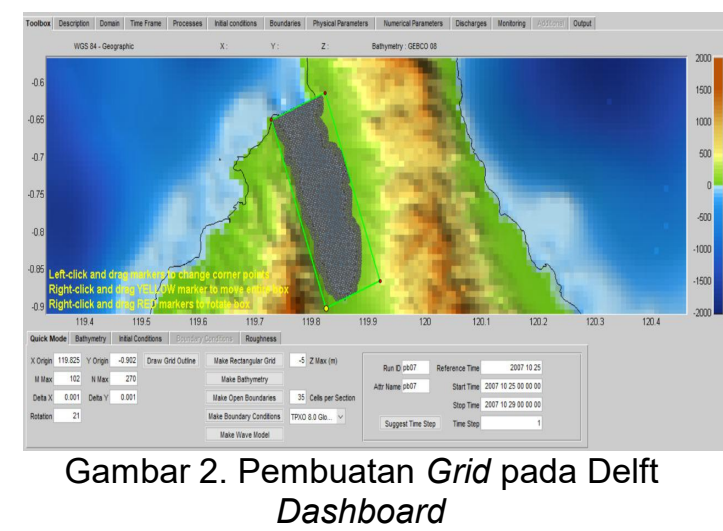

Setelah grid selesai dipersiapkan, selanjutnya dilakukan pengaturan referensi waktunya, dimana diset start time tanggal 25 Oktober 2007 pukul 00.00 WIB dan stop time tanggal tanggal 29 Oktober 2007 pukul 00.00 WIB. Selanjutnya set make bathymetry dan open boundaries dibuat 35 cells per section. Terakhir, setting boundary condition TPXO 8.0. Selanjutnya di running, seperti gambar di bawah ini.

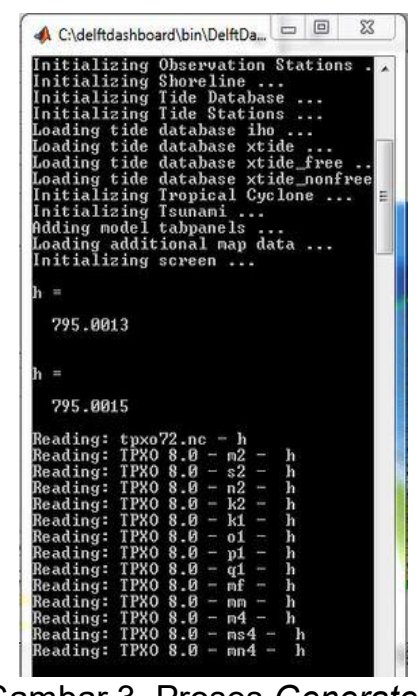

Gambar 3. Proses Generate

Terdapat sedikit catatan, dimana setelah dilakukan eksperimen terhadap hasil generate grid, maka desain sebaiknya digeser atau dilebihkan sedikit di bagian kiri dan dikurangkan sedikit pada bagian kanan, hal tersebut disebabkan terdapat overlap ke kanan sedikit ketika telah di load ke dalam aplikasi Delft 3D. Setelah selesai di-generate, hasilnya dapat diolah lebih lanjut dengan quickin pada aplikasi Delft 3D. Data awal hasil proses generate tersebut harus dikolaborasi dengan beberapa sumber data bathymetry, dimana data yang digunakan adalah data hasil bathymetry PusAir Kementerian ESDM dan atau Batnas. 
Tentu data-data hasil bathymetry tidak dapat sempurna mengisi wilayah grid yang ditentukan. Hal tersebut dikarenakan, pengambilan data bathymetry untuk spesifikasi laut cukup dalam menggunakan kapal dengan yang dilengkapi multibeam echosounder. Sedangkan untuk laut dangkal dan pesisir pantai menggunakan rubber boat yang dilengkapi dengan singlebeam echosounder. Beberapa data bathymetry tersebut tidak semuanya meliputi/cover wilayah grid yang ditentukan, sehingga dilakukan covering data menggunakan teknik rata-rata dan triangulasi data. Diperlukan ketelitian dan keterampilan pengolah untuk mendapatkan hasil yang mendekati kondisi nyata dari wilayah Teluk Palu tersebut. Gambar berikut adalah hasil kolaborasi data dan manipulasi data bathymetry sehingga data dapat lebih akurat mendekati aslinya.

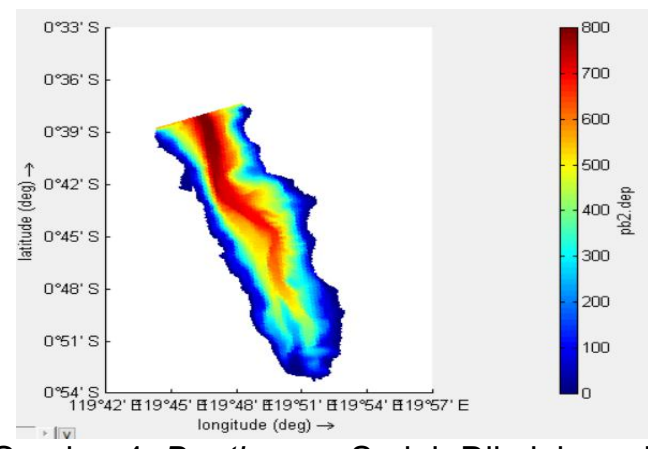

Gambar 4. Depth yang Sudah Dikolaborasi

Depth yang sudah dikolaborasikan tersebut dapat digunakan untuk tide simulation. Penetapan durasi waktu dapat mempengaruhi lama proses modeling, namun harus memenuhi ketentuan courant number. Oleh sebab itu dibatasi waktu pengambilan data tide antara tanggal 25 hingga 29 Oktober 2007 saja. Berikut ini adalah proses running tide simulation.

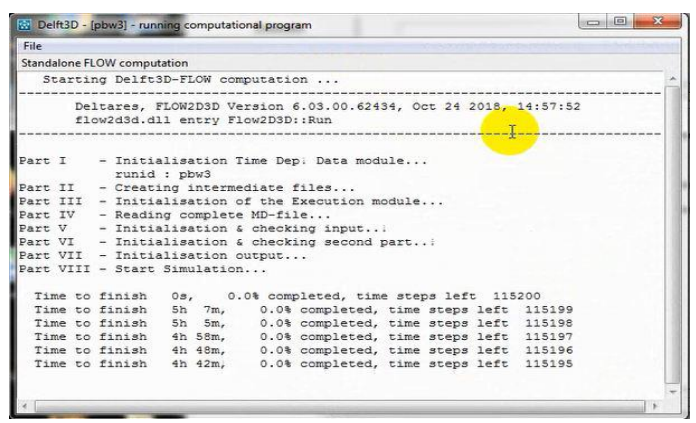

Gambar 5. Running Tide

Berdasarkan hasil running tersebut, dihasilkan grafik tide dalam kurun waktu 25 hingga 29 Oktober 2007. Berdasarkan grafik tersebut, terlihat tide peak terjadi pada tanggal 28 Oktober, dimana menyentuh angka 1,45 m.

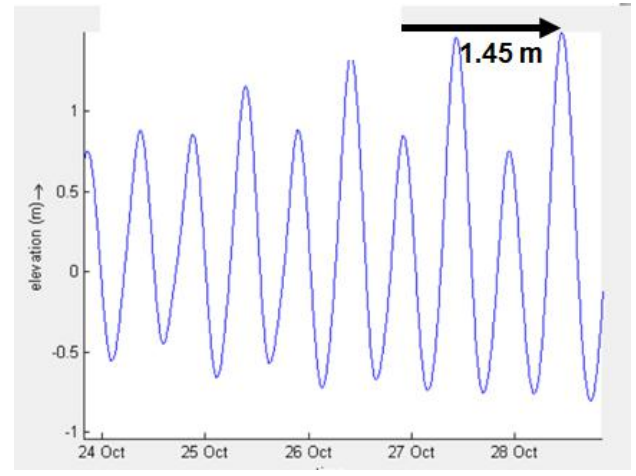

Gambar 6. Tide Hasil Simulasi

Selain tide, dapat dilihat juga hasil storm surge. Pada kasus Palu, efek angin untuk menginduksi storm surge disimulasikan dengan mempertimbangkan penambahan nilai constant $0,08 \mathrm{~m}$ dan peningkatan storm surge 0,006 dengan mempertimbangkan tekanan rata-rata dan tekanan minimum pada permukaan laut Teluk Palu, dimana hal tersebut dipengaruhi oleh efek barometer terbalik.

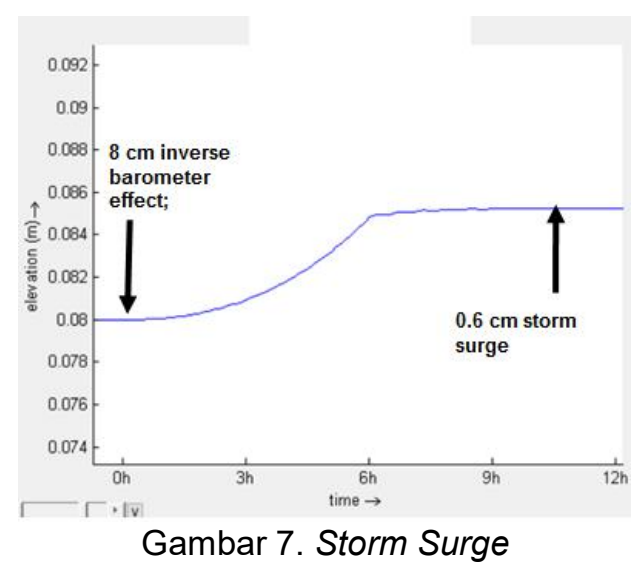

Di sisi lain, kecepatan angin selama periode pengembalian 100 tahun di wilayah Teluk Palu adalah $10,35 \mathrm{~m} / \mathrm{s}$. Sehingga dapat disimpulkan bahwa storm surge memiliki pengaruh besar minimal terhadap peningkatan permukaan air laut.

\subsection{Wave}

Pada pengolahan pemodelan gelombang laut menggunakan aplikasi Delft 3D dilakukan dalam tiga tahapan, yaitu tahap persiapan, tahap penentuan parameter model gelombang laut, dan pemrosesan.

\subsubsection{Persiapan}

Pada tahap persiapan dilakukan proses pembuatan model berdasarkan hasil bathymetry. Terdapat dua tiga model yang disiapkan dalam tahapan ini, dengan rincian sebagai berikut: 
A. Model 1 memiliki spesifikasi
a. Bathymetry: Batnas,
Deltares, Balai Pantai, BPPT.
b. $\mathrm{dx}$ Grid 1: $\pm 111 \mathrm{~m}$
c. $\mathrm{dx}$ Grid 2: $\pm 27 \mathrm{~m}$ (Nesting)
d. Wind Data: ECMWF ERA5 39 years
e. Wind Analysis: 100 year return period (Deltares)

B. Model 2 memiliki spesifikasi
a. Bathymetry: Batnas, Deltares, Balai Pantai, BPPT.
b. dx Grid 3: $\pm 27 \mathrm{~m}$
c. Wind Data: Mutiara SIS Al-Jufrie Airport
d. Wind Analysis: Consultant report
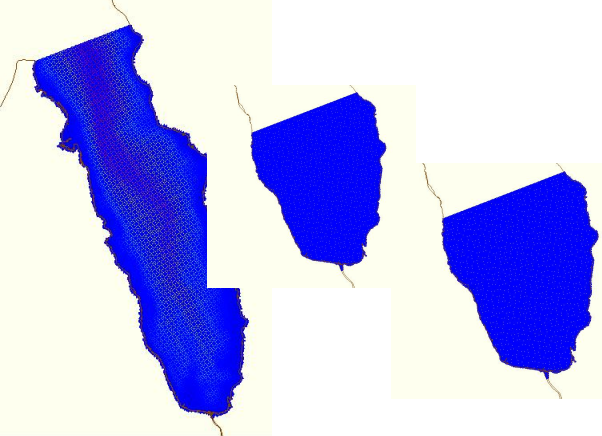

Gambar 8. Grid 1, Grid 2, dan Grid 3

Pembuatan bathymetry menggunakan Quickin yang tersedia pada aplikasi Delft 3D. Tujuan dari pembuatan bathymetry ini adalah mengisi bagian depth yang tidak memenuhi luasan bidang grid menggunakan triangular interpolation, internal diffusion, uniform, dan lainlainnya.

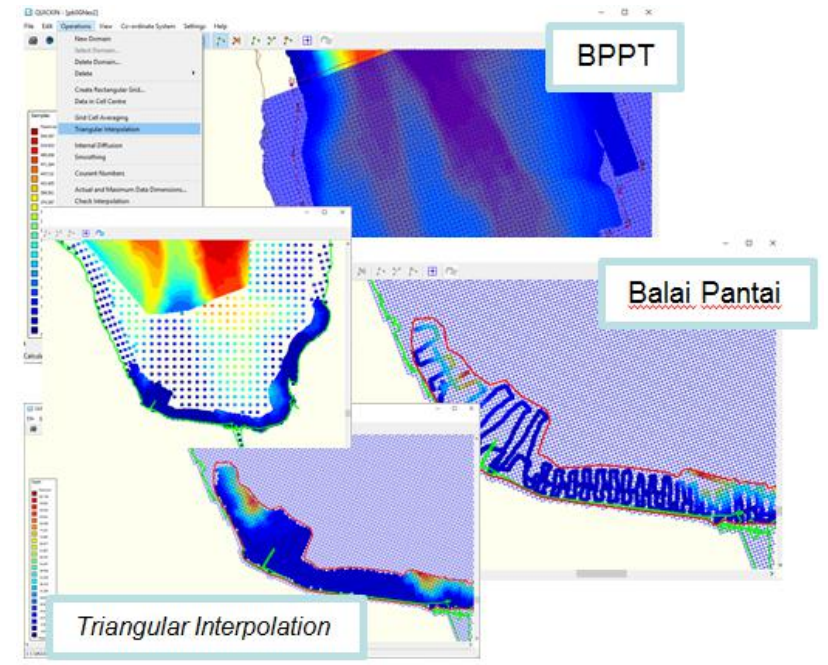

Gambar 9. Proses Cover pada Depth

Hasil dari pembuatan bathymetry adalah depth 1 dan depth 2, dimana depth 1 memiliki resolusi $111 \mathrm{~m}$ dan depth 2 memiliki resolusi 27 m.

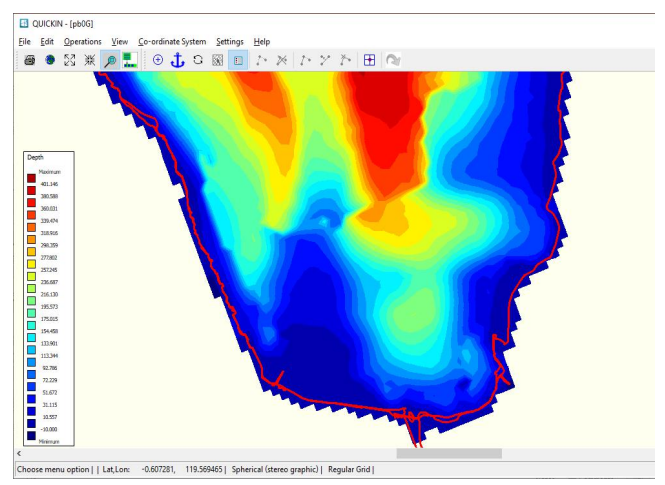

Gambar 10. Depth 1

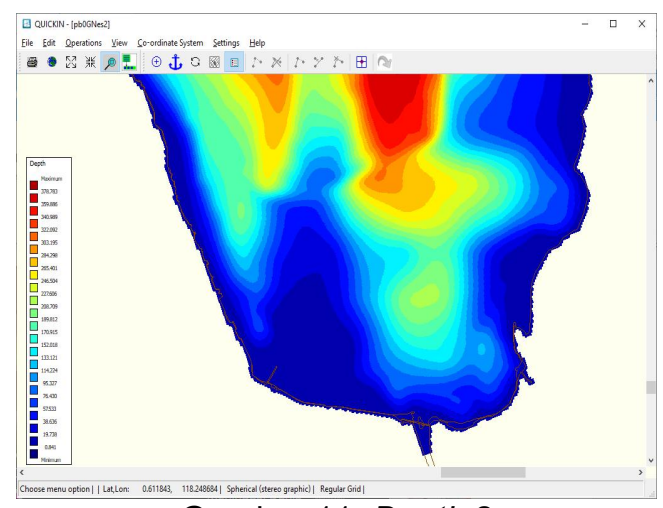

Gambar 11. Depth 2

\subsubsection{Model Gelombang Laut}

Pada tahapan pengolahan model gelombang laut ini terdiri dari mulai grid, time frame, boundary, obstacles, parameter fisik, parameter numerik, parameter keluaran.

\section{A. Grid}

Pada pengaturan grid dilakukan proses import grid yang diperlukan, lalu dipilih bathymetry yang digunakan. Selanjutnya, pada spectral resolution, sesuai SWAN 2000, halaman 39 dan 49, maka frekuensi rendahnya diberi nilai $0,03 \mathrm{~Hz}$, frekuensi tingginya diberi nilai $1 \mathrm{~Hz}$, dan number frequency bins diberi nilai 37. (Delft. 2019b).

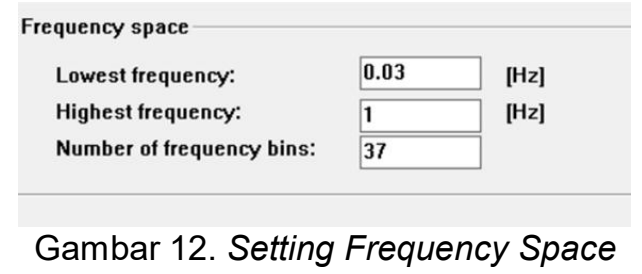

Setelah model 1 selesai, maka dilakukan proses nesting pada model 1, dimana grid kedua yang diberi nesting di grid pertama. Sedangkan model 2 tidak diberi nesting. 
B. Time Frame

Pada time frame dilakukan pengaturan water level corrections, dimana diperoleh dari nilai pasang tertinggi $\pm 1,45 \mathrm{~m}$ (pada bulan 28 Oktober 2007 dan sesuai hasil tide hasil simulasi sebelumnya), apabila ditambahkan ke nilai pasang surut karena storm surge/gelombang badai yang bernilai $\pm 0,50 \mathrm{~m}$ menjadi $1,55 \mathrm{~m}$ (return period 100 years). Nilai $1,55 \mathrm{~m}$ inilah yang dimasukkan dalam pengaturan water level corrections.

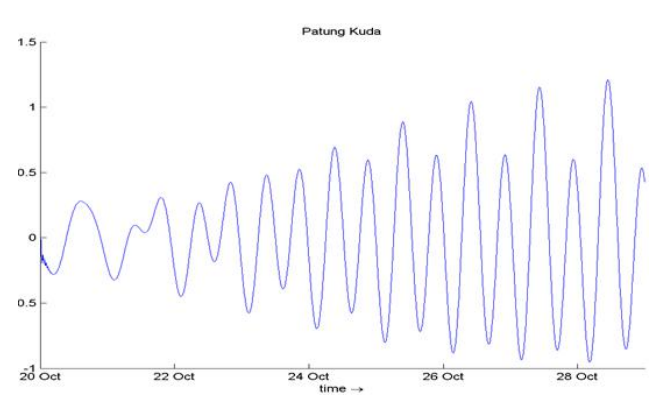

Gambar 13. Tidal Modelling

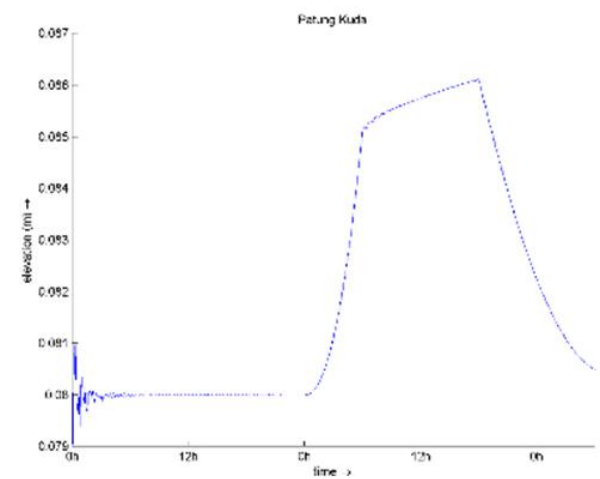

Gambar 14. Storm Surge Modelling

C. Boundary

Selanjutnya pada tahap pengaturan Boundary/batas harus berdasarkan orientasi, koordinat grid, atau koordinat MN. Sehingga pada gambar berikut ditetapkan boundary pada model 1 dan model 2 .

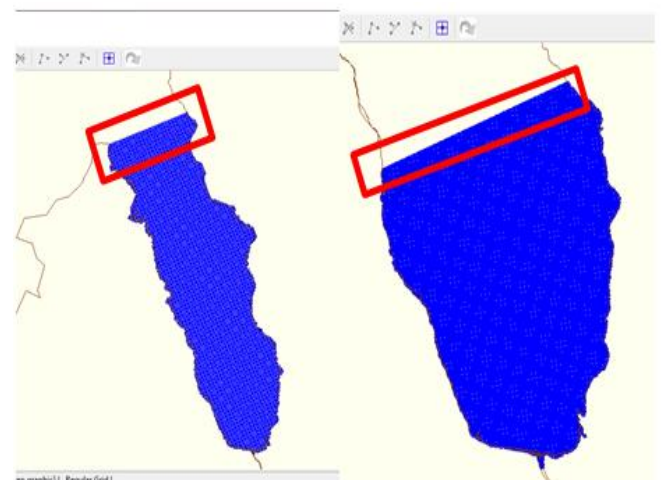

Gambar 15. Boundary Model 1 dan Model 2
Pada bagian boundary akan muncul koordinat $\mathrm{MN}$, sesuai visualisasi pada gambar di atas, sehingga perlu dilakukan penyesuaian nilai parameter pada masingmasing model. Kemudian menentukan nilai kondisi gelombang datangnya konstan atau sebatas boundary saja. Selanjutnya menentukan parameter spectral space dan uniform boundary condition juga ditentukan, ada beberapa nilai yang perlu diisi dan ada juga yang sudah memiliki nilai namun perlu disesuaikan nilainya.

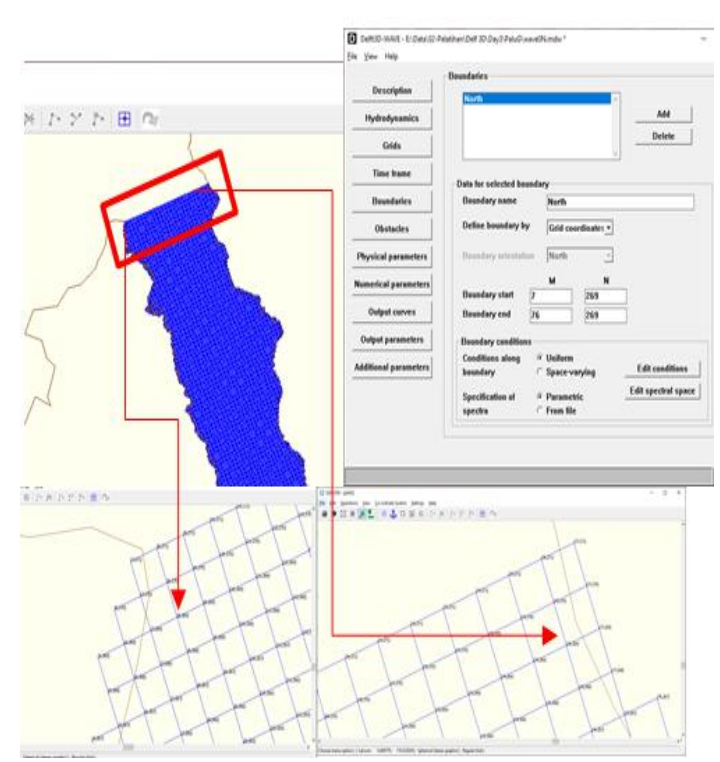

Gambar 16. Boundary Model 1

Boundary start pada model $1 \mathrm{M}, \mathrm{N}$ bernilai 7;269. Sedangkan boundary end pada model $1 \mathrm{M}, \mathrm{N}$ bernilai 76;269. Selanjutnya boundary conditions dipilih dalam bentuk uniform dan specification of parametic. Boundary condition juga dilakukan penetapan parameter berdasarkan referensi analisis wave (39 years of ECMWF ERA5 model data) (https://www.ecmwf.int). Wave analysis di bawah dijadikan acuan dalam menentukan parameter boundary condition pada kedua model.
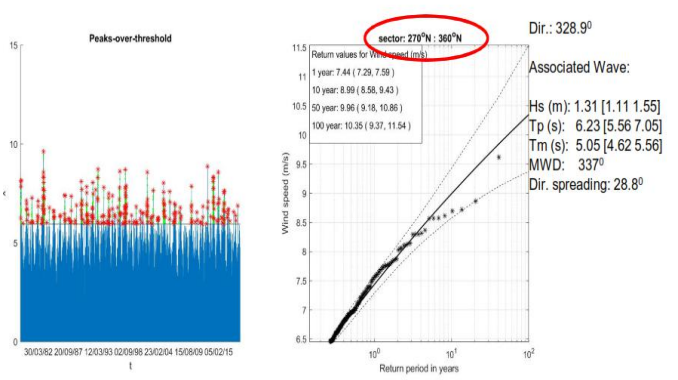

Gambar 17. Wave Analysis 
Berdasarkan referensi parameter di atas, maka pada model 1 pengaturan nilai uniform boundary condition adalah significant hight wave 1,31 $\mathrm{m}$, peak period Tp 6,23 s, direction (nautical) $337 \mathrm{deg}$, dan directional spreading 28,8 deg. Selain itu, terdapat keterangan bahwa rata-rata return periode dari kecepatan angin 100 tahun adalah $10,36 \mathrm{~m} / \mathrm{s}$ dari sektor $270^{\circ} \mathrm{N}: 360^{\circ} \mathrm{N}$.

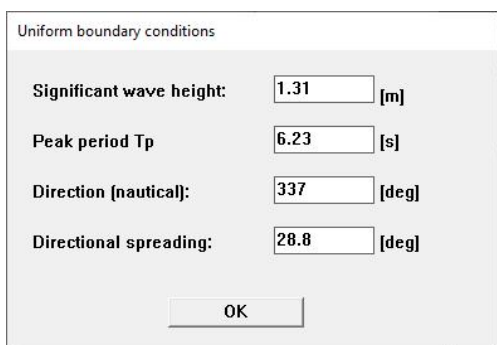

Gambar 18. Uniform Boundary Model 1

Penetapan nilai uniform boundary condition adalah significant hight wave 1,31 m, peak period Tp 6,23 s, direction (nautical) 337 deg, dan directional spreading $28,8 \mathrm{deg}$.

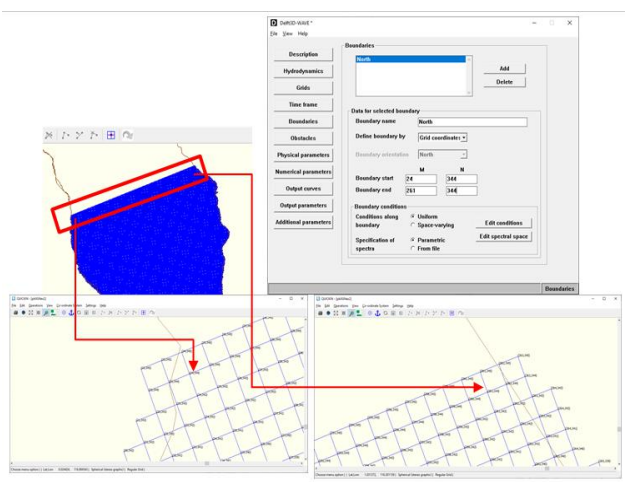

Gambar 19. Boundary Model 2

Boundary start pada model $2 \mathrm{M} ; \mathrm{N}$ bernilai $24 ; 344$. Sedangkan boundary end pada model 2 M,N bernilai 261;344. Selanjutnya boundary conditions dipilih dalam bentuk uniform dan specification of parametic.

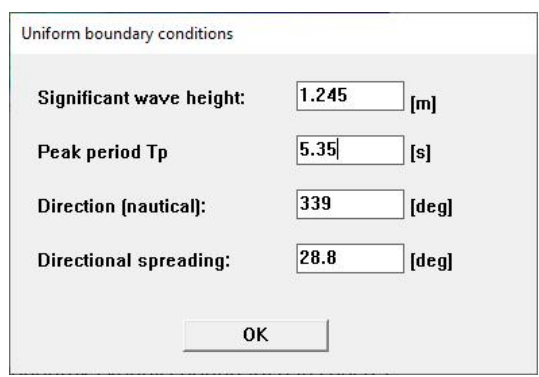

Gambar 20. Uniform Boundary Model 2

Berdasarkan referensi parameter wave analysis, maka pada model 2 pengaturan nilai uniform boundary condition adalah significan hight wave 1,245 m, peak period
Tp 5,35 s, direction (nautical) $339 \mathrm{deg}$, dan directional spreading $28,8 \mathrm{deg}$.

D. Obstacles

Penetapan parameter pada suatu pemodelan pasti disesuaikan dengan kondisi aslinya, supaya hasilnya semakin mendekati harapan yang diinginkan. Penambahan data obstacle tentunya akan mempengaruhi hasil akhir. Penentuan obstacle menggunakan aplikasi Google earth yang diakses pada bulan Oktober 2018 (https://earth.google.com).

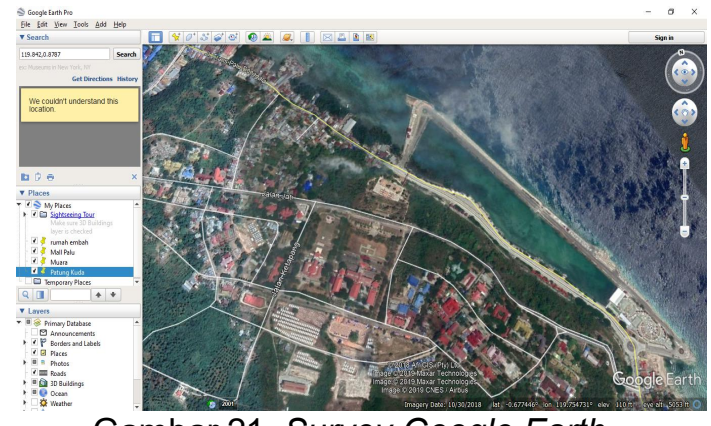

Gambar 21. Survey Google Earth

Berhubung area Teluk Palu cukup luas dan dampak dari gempabumi dan tsunami sangat luas, maka ditentukan beberapa lokasi obstacle. Ditentukan lima buah obstacle dengan tipe dan koordinat masing-masing parameternya, berdasarkan referensi google earth yang telah dimasukkan ke dalam aplikasi. Obstacle tersebut diberi nama Pulau1, Pulau2, Pulau Jembatan, Reklamasi, dan Groin.

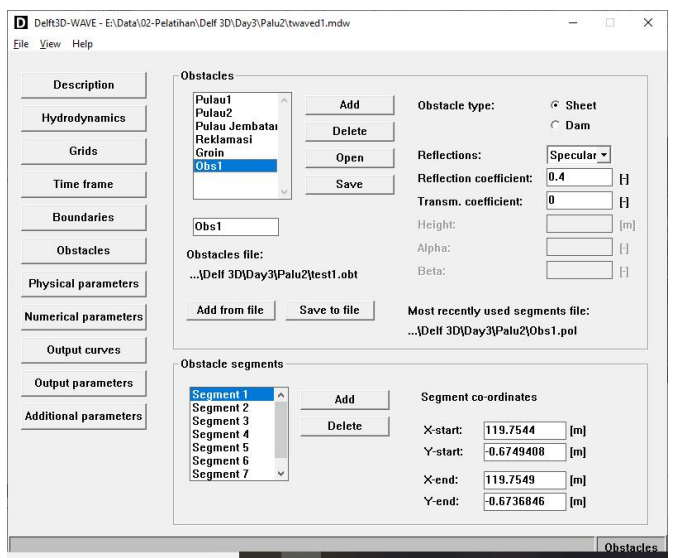

Gambar 22. Obstacle

E. Parameter fisik

Parameter fisk memiliki empat variabel yang harus ditentukan, yaitu constants, wind, processes, dan various. Ada yang sudah otomatis tertampil angka default oleh sistem, namun ada juga yang perlu diubah sesuai kebutuhan. Selanjutnya 
dilakukan tahap pengaturan bagian constant berupa nilai gravity $9,81 \mathrm{~m} / \mathrm{s}^{2}$; water density $1025 \mathrm{~kg} / \mathrm{m}^{3}$; North w.r.tx-axis 90 deg; minimum depth $0,5 \mathrm{~m}$; convention nautical; force wave energy dissipation rate $3 D$, dan wave set up none.

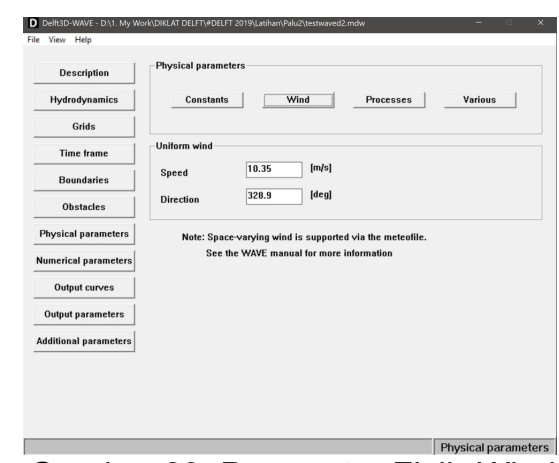

Gambar 23. Parameter Fisik Wind

Penentuan parameter wind ditentukan oleh data wave analysis, dimana nilai speed $10,35 \mathrm{~m} / \mathrm{s}$ dan direction 328,9 deg. Penentuan parameter processes akan mempengaruhi parameter fisik dari SWAN. Koefisien dari formulasi JONSWAP bernilai sama hingga 0,067 untuk nilai default dari kondisi wind sea dan bernilai sama hingga 0,038 untuk kondisi swell. Pengaturan various akan mempengaruhi propagasi wave pada parameter fisik dan spectral space di SWAN.

F. Parameter numerik

Pengaturan parameter numerik ini akan mempengaruhi kriteria dari mengakhiri prosedur iterasi, dimana akurasi kriteria yang dibutuhkan adalah $1 \%$. Relative change di-set $0.01 \mathrm{Hm}$, percentage of wet grid points $99 \mathrm{pq}$, relative change w.r.t. mean value $\mathrm{Hs} 0.01 \mathrm{H}$, Tm01 $0.01 \mathrm{H}$ dan maksimum number of iterations 25 kali.

G. Parameter keluaran

Parameter keluaran berisi lokasi mana saja yang dijadikan titik pantau hasil pemodelannya. Penentuan titik pantau didasari oleh jumlah sebaran manusia dan bangunan pada suatu wilayah. Penentuan ini menggunakan survei menggunakan google earth, sehingga ditetapkan lokasi pantau sebanyak 5 titik, dimana terbanyak terdapat di tenggara Teluk Palu. Selanjutnya koordinat titik pantau dimasukkan ke dalam aplikasi.

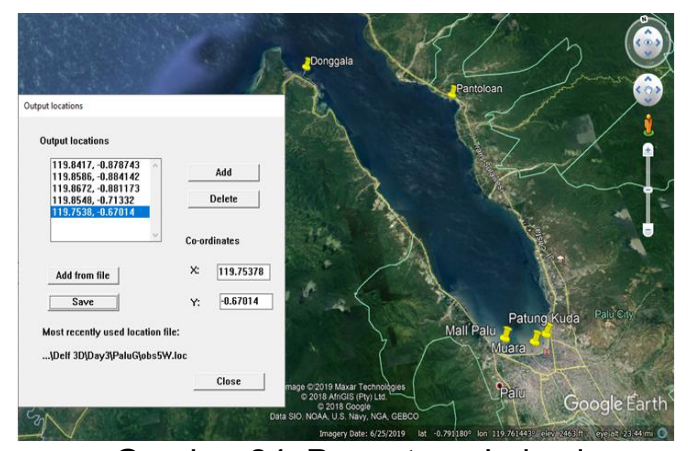

Gambar 24. Penentuan Lokasi

\subsubsection{Pemrosesan}

Setelah semua parameter sudah ditentukan dan diatur, maka proses selanjutnya adalah melakukan iterasi dengan tujuan untuk mendapatkan hasil dari Model 1 dan Model 2.

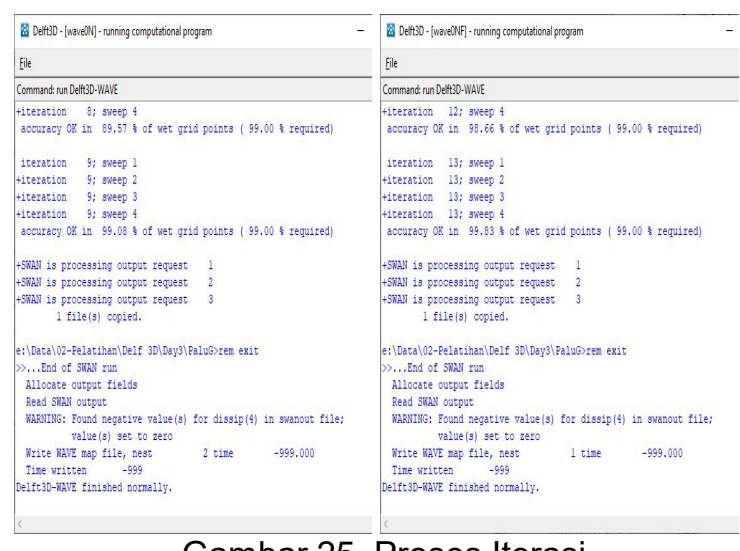

Gambar 25. Proses Iterasi

Dari hasil iterasi tersebut maka dihasilkan gambar-gambar hasil pemodelan dan data. Terdapat 3 kategori gambar dan data, yaitu model 1, model 1 dengan nesting dan model 2. Hasil gambar pemodelan pertama berupa significant height wave (Hs). Adapun hasilnya dapat dilihat pada gambar berikut.

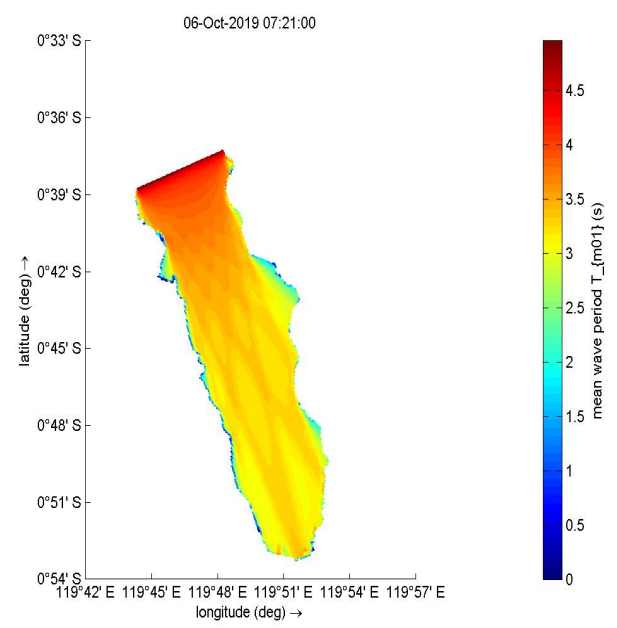

Gambar 26. Significant Wave Height Model 1 


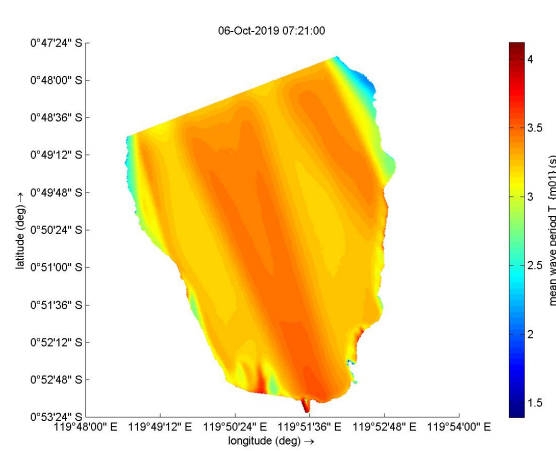

Gambar 27. Significant Wave Height Model 1 dengan Nested

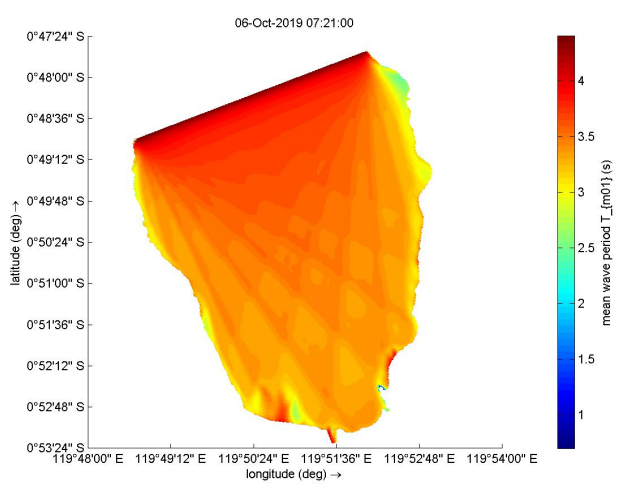

Gambar 28. Significant Wave Height Model 2

Berdasarkan hasil pemodelan di atas, wave condition of coast bernilai antara 0,9 hingga 1,2 $\mathrm{m}$.

\subsection{Analisis Sea Level Rise}

Penentuan sea level rise atau kenaikan permukaan laut pada Teluk Palu ditentukan berdasarkan data penelitian dari beberapa institusi di bawah ini.

\subsubsection{Referensi Bappenas}

Pada referensi Bappenas, dimana menggunakan empat metode, yaitu menggunakan data altimeter, data tidal gauge, model IPCC, dan penelitian mengenai penambahan dinamika perubahan massa es dan pertemuan es di Greenland dan Antartika.

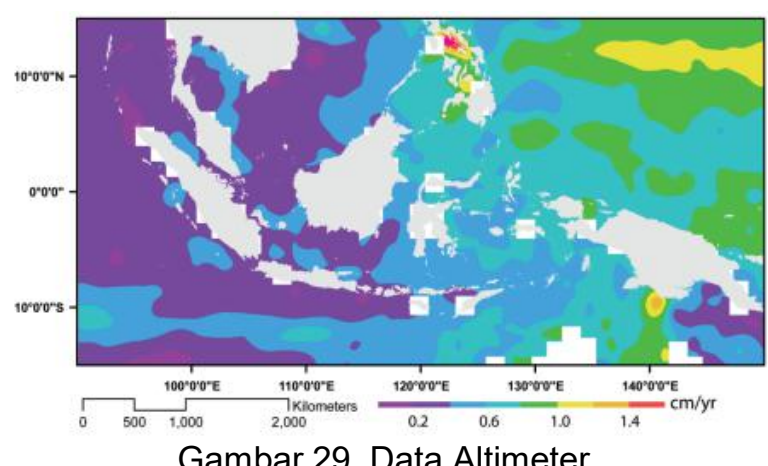

Gambar 29. Data Altimeter

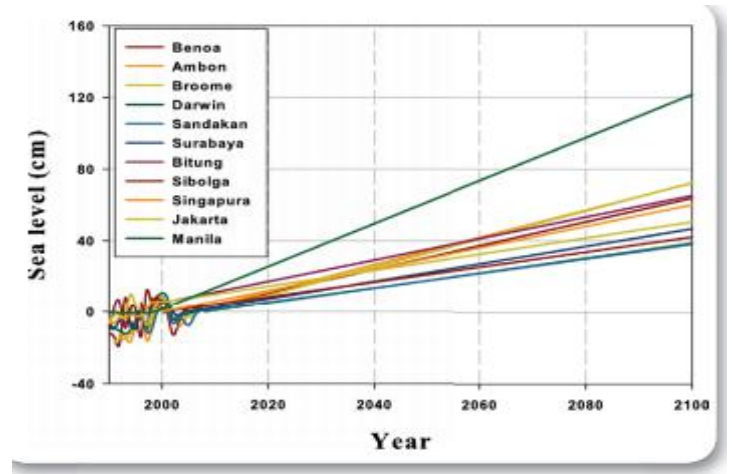

Gambar 30. Data Tidal Gauge

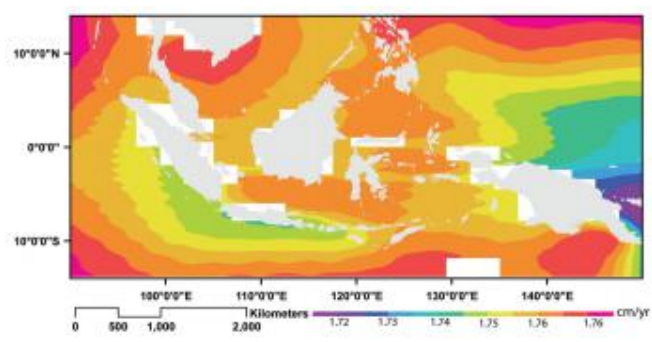

Gambar 31. Hasil Penelitian Penambahan Dinamika Perubahan Massa Es dan Pertemuan Es di Greenland dan Antartika

Data altimeter memiliki nilai sea level rise dari 1 hingga 1,4 cm per tahun. Data tidal gauge memiliki nilai sea level rise dari 0,2 hingga $1 \mathrm{~cm}$ per tahun. Model IPCC memiliki nilai sea level rise dari 0,4 hingga $1,2 \mathrm{~cm}$ per tahun. Hasil penelitian mengenai penambahan dinamika perubahan massa es dan pertemuan es di Greenland dan Antartika memiliki nilai sea level rise mencapai $1,75 \mathrm{~cm}$ per tahun (Bappenas, 2010).

\subsubsection{Referensi National Intelligence Council}

Pada referensi National Intelligence Council, dimana menggunakan metode pemodelan IPCC MMD, dimana pada akhir abad 21 diperkirakan kenaikan mencapai 30 hingga $40 \mathrm{~cm}$. Sehingga nilai sea level rise tiap tahunnya adalah 1,5 hingga $2 \mathrm{~cm}$ (National Intelligence Council, 2009).

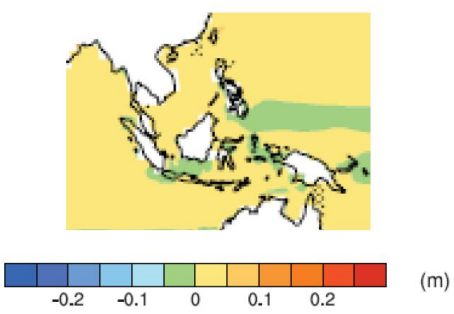

Gambar 32. Referensi National Intelligence Council

\subsubsection{Referensi WWF}

Pada referensi climate change di Indonesia (WWF), sea level rise terdiri dari dua buah referensi penelitian lainnya. Referensi pertama menyebutkan bahwa sea level rise meningkat 1 hingga $3 \mathrm{~mm}$ per tahun di wilayah pesisir Asia 
dan kondisi ini memungkinkan mencapai $5 \mathrm{~mm}$ per tahun hingga akhir abad 21. Referensi kedua menyebutkan bahwa seiring dengan meningkatnya jumlah penduduk dari 13 juta menjadi 94 juta di wilayah Asia Selatan, di bawah skenario kenaikan permukaan laut yang sangat konservatif, mencapai $40 \mathrm{~cm}$ hingga tahun 2100 (Case et al., 2007).

\subsubsection{Referensi Potsdam Institute for Climate Impact Research and Climate Analytics}

Pada referensi ini menggunakan metode pemodelan CMIP5, dimana menggunakan pemodelan yang telah dilakukan berdasarkan parameter pencairan es di kutub yang terjadi hingga akhir tahun 2090. Apabila kenaikan suhu mengalami kenaikan $2^{\circ} \mathrm{C}$, maka kenaikan air laut mencapai $75 \mathrm{~cm}$. Sedangkan jika kenaikan suhu mengalami kenaikan $4^{\circ} \mathrm{C}$, maka kenaikan air laut mencapai $100 \mathrm{~cm}$. Sehingga nilai sea level rise dalam kurun waktu 100 tahun di angka $75 \mathrm{~cm}$, sehingga nilai kenaikan per tahunnya adalah 0,75 cm. (Potsdam Institute for Climate Impact Research and Climate Analytics, 2013)
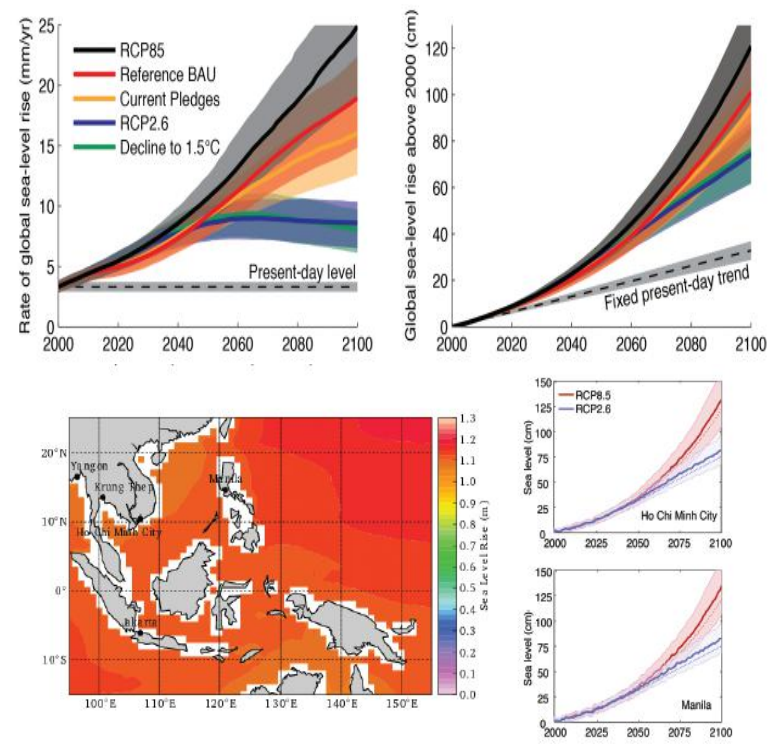

Gambar 33. Pemodelan CMIP5

\subsubsection{Prediksi Berdasarkan Referensi}

Beberapa referensi di atas saling berhubungan erat dengan sea level rise, namun harus dipilih satu referensi yang dijadikan patokan untuk menentukan sea level rise yang dipilih dalam kajian ini. Apabila dicermati, faktor mencairnya es di kutub merupakan ancaman serius yang akan terus kontinu berjalan secara masiv dari tahun ke tahun dari hasil pemanasan global yang terjadi di bumi.

Hal tersebut dapat dibuktikan pada 2006, Bappenas melakukan riset yang menyebutkan bahwa sea level rise berdasarkan pencairan es di Greenland dan Antartika mencapai $1,75 \mathrm{~cm}$ per tahun. Nilai tersebut sebaiknya perlu dikaji lebih lanjut, karena margin nilai sea level rise cukup tinggi dan cukup sukar untuk terealisasi pada setiap tahunnya, kecuali terdapat kejadian khusus yang di trigger kondisi kenaikan suhu yang cukup signifikan, sehingga sea level rise akan naik secara tiba-tiba namun bukan proses yang kontinu.

Pada kajian ini dipilih referensi sea level rise berdasarkan tahun termutakhir, yaitu referensi dari Potsdam Institute for Climate Impact Research and Climate Analytics. Berdasarkan referensi laporan World Bank pada tahun 2010 menyebutkan bahwa nilai rata-rata sea level rise adalah $0,75 \mathrm{~cm}$ per tahun. Nilai tersebut cukup logis untuk terealisasi pada setiap tahunnya.

\subsection{Menentukan Ketinggian Sea Wall}

Seperti pada tujuan awal penulisan ini, yaitu membuat analisis ketinggian desain tanggul laut yang cocok untuk meminimalisir hilangnya garis pantai pasca tsunami tahun 2018 di Teluk Palu berdasarkan parameter tide, storm surge, wave, dan sea level rise (SLR). Adapun rumus menentukan ketinggian sea wall adalah sebagai berikut.

$$
\text { Ketinggian }=\text { tide }+ \text { storm } \text { surge }+ \text { wave }+S L R
$$

Berdasarkan pengkajian pada sub bab sebelumnya didapatkan tinggi tide mencapai 1,45 $\mathrm{m}$; nilai maksimum storm surge sekitar 0,086 m; kondisi wave antara 0,90 hingga 1,25 m; dan sea level rise rata-rata per tahun adalah $0,75 \mathrm{~cm}$. ketinggian mencapai 3,186-3,536 m.

\section{KESIMPULAN DAN SARAN}

Berdasarkan pembahasan di atas dapat ditarik kesimpulan bahwa telah dilaksanakan simulasi pemodelan menggunakan aplikasi Delft 3D dan mengkaji beberapa referensi yang relevan dengan tanggul laut, sehingga didapatkan hasil sebagai berikut: kecepatan angin 10,35 m/s di area Teluk Palu, maka tinggi tide mencapai $1,45 \mathrm{~m}$; nilai maksimum storm surge sekitar $0,086 \mathrm{~m}$; kondisi wave antara 0,90 hingga $1,25 \mathrm{~m}$; dan sea level rise rata-rata per tahun adalah $0,75 \mathrm{~cm}$. Apabila dikalkulasi akan didapat hasil analisis desain ketinggian tanggul yang cocok untuk meminimalisir hilangnya garis pantai pasca tsunami tahun 2018 di Teluk Palu dengan ketinggian mencapai 3,186-3,536 m.

Sebagai saran, perlu dilakukan pengkajian lanjutan mengenai lifetime tanggul laut, penelitian mengenai tebal tanggul laut, pemetaan untuk lokasi penempatan tanggul laut agar lebih efektif serta efisien, faktor safety margin, dan faktor-faktor yang lainnya. 


\section{PERSANTUNAN}

Ucapan terima kasih yang sebesar-besarnya penulis sampaikan kepada PusAir PU, Bapak Deepak, Bapak Irham, Bapak Leo, Bapak Heru, Bapak Harris, Bapak Wisyanto, Ibu Dyah, Ibu Puspa, Ibu Syakira dan segenap tim Jurnal Alami yang telah banyak membantu dalam diskusi penyusunan jurnal ini, hingga jurnal ini selesai disusun.

\section{DAFTAR PUSTAKA}

Bappenas. 2010. Indonesia Climate Change Sectoral Roadmap ICCSR: Analysis and Projection of Sea Level Rise and Extreme Weather Events. 28 - 37.

Case, Michael, F. Ardiansyah, E. Spector. 2007. WWF Climate Change in Indonesia Implications for Humans and Nature. Researchgate. 6-7.

Delft. 2019a. Simulation of multi-dimensional hydrodynamic flows and transport phenomena, including sediments: HydroMorphodynamics. The Netherlands. Deltares. $1-130$.

Delft. 2019b. Simulation of short-crested waves with SWAN: Hydro-Morphodynamics. The Netherlands. Deltares. 1-165.

ECMWF. 2018. ERA5 dataset from 1950 until pressent. [terhubung berkala]. https://www.ecmwf.int/en/forecasts/dataset s/ reanalysis-datasets/era5 diakses [1 Oktober 2019].

Fedryansyah, Muhammad, R. Pancasilawan, Ishartono. 2016. Penanggulangan Bencana di Masyarakat Desa Studi Di Desa Cipacing, Desa Cileles, dan Desa Cikeruh, Kecamatan Jatinangor, Kabupaten Sumedang. Social Work Jurnal, 8(1): 11-16.

Google Earth. 2019. Sulawesi Island. [terhubung berkala]. https://earth.google.com/web [4 Oktober 2019].

Kementerian Kesehatan Republik Indonesia. 2020. Infografis Final Kejadian Bencana Gempa Bumi dan Tsunami di Sulawesi Tengah.http://pusatkrisis.kemkes.go.id/infogr afis-final-kejadian-bencana-gempa-bumidan-tsunami-di-sulawesi-tengah. [1 Maret 2020].

National Intelligence Council. 2009. Southeast Asia and Pacific Islands: The Impact of Climate Change to 2030. 25-26.

Potsdam Institute for Climate Impact Research and Climate Analytics. 2013. Turn Down the Heat: Climate Extremes, Regional Impacts, and The Case for Resilience. Washington DC. International Bank for Reconstruction and Development / The World Bank. 76-77

Pribadi, Sugeng, I. Gunawan, J. Nugraha, T. Haryono, E. Susanto, I. Romadon, C. Basri,
A. Mustarang, Heriyanto. 2019. Merekam Jejak Tsunami Teluk Palu 2018. Laporan Survey Tsunami BMKG. Jakarta.

RRI. 2020. Kapal Baruna Jaya I BPPT Survei Batimetri di Laut Sulawesi Tengah. http://rri.co.id/post/berita/586192/teknologi/ kapal_riset_baruna_jaya_i_bppt_terus_laku kan_survei_batimetri_di_laut_sulawesi_teng ah. $\overline{h t m l}$. [1 $\overline{\text { Maret 2020] }}$

Suharto, E. 2008. Analisis Kebijakan Publik: Panduan Praktis Mengkaji Masalah dan Kebijakan Sosial. Bandung. Alfabeta. Edisi revisi. 102-145.

Zulham, Armen. 2014. Pembangunan Giant Sea Wall: Bermanfaatkah Bagi Masyarakat Perikanan. Risalah Kebijakan Pertanian dan Lingkungan 1(3): 129-134. 